\title{
Topical diclofenac: Clinical effectiveness and current uses in osteoarthritis of the knee and soft tissue injuries.
}

Maggi Banning, EdD, M.Sc, PGDE, B.Sc. Senior lecturer, Brunel University.

Background: Diclofenac is a commonly used non steroidal anti-inflammatory drug (NSAID) for symptom control in osteoarthritis (OA) of the knee and soft tissue injuries. Although treatment with oral diclofenac is associated with serious adverse effects involving both the gastrointestinal and renal systems, these adverse effects are thought to be limited with topical diclofenac formulations without loss of efficacy. Objective: the aim of this review is to explore the available evidence in relation to the pharmacokinetics, efficacy and reported adverse effects of the topical diclofenac formulations available. Results/conclusions: In the majority of studies examined, topical diclofenac formulations with sodium lotion, lecithin or epolamine gel, patch or plaster were either superior or equivalent to oral diclofenac formulations or placebo. Topical diclofenac significantly reduced pain and morning stiffness and improved physical function and patient global assessment without major adverse effects reported in patients with $\mathrm{OA}$ of the knee and provided significant pain relief in patients with sports and soft tissue injuries involving the ankle, knee or shoulder. In the majority of studies reported the predominant adverse effect involved pruritus or rash at the site of application or nausea. The principle outcome of these studies is that topical diclofenac is a safe and practical alternative as a method of treatment in OA of the knee or as an alternative treatment for sports and soft tissue injury. 
Key words: NSAIDs, diclofenac, pharmaceutical formulations, osteoarthritis, pain relief, tolerability.

\section{Introduction}

Historically NSAIDs have been used to assist the resolution of pain in conditions of OA of the knee and sports and soft tissue injuries. A major drawback of using oral forms of NSAIDs such as diclofenac is the high incidence of major adverse effects such as gastrointestinal bleeding, gastric ulceration and renal disease implications. The use of topical formulations of diclofenac is thought to be as efficacious as oral formulations without the risk of systemic side effects. Topical diclofenac is thought to reduce inflammation via inhibition of the COX 2 isoenzyme. This review addresses the current evidence of the efficacy of topical formulations of diclofenac for treatment of OA of the knee and soft tissue and sports injury.

\section{Overview}

Musculoskeletal conditions range from intra articular disorders such as rheumatoid arthritis and osteoarthritis, injuries that involve simple ligaments such as sprains and extra articular joint disorders such as fibromyalgia and myofascial pain. In the UK, ankle sprains are a common soft tissue injury and occur in 53 per 10,000 population [1].By comparison osteoarthritis (OA) is a common joint disorder. Although radiographic evidence of $\mathrm{OA}$ is common in persons aged 65 years and over [2] often the severity of symptoms does not correlate well with pathogenic alterations viewed radiographically [3]. The knee joint is a common site for the development of OA [4]. 
Up to $11 \%$ of older people present with relevant clinical symptoms of OA of the knee along with variable forms of disability and long-term pain that requires symptom management [5]. It is postulated that OA will become a global cause of disability in patients by the year 2020 [6].

OA is generally thought of as a disorder of middle-aged and older people. Commonly affected sites include: hip, knee and spine [7]. Typical symptoms include: joint pain in and around the joint site, morning stiffness lasting up to 30 minutes, loss of function, immobility and joint instability. Onset of symptoms is insidious. Pain is generally worse during motion and can be alleviated by rest. Patients with OA of the knee may complain of alterations to the gait and often experience a variety of forms of pain varying from a sharp pain to a dull constant ache [7].

Pain is a complex sensory process which is related to specific tissue damage. During trauma to the skin, blood vessels release inflammatory mediators such as prostaglandins, neuropeptides such as substance $\mathrm{P}$ and calictonin-gene related peptide. These substances act as a stimulus and cause peripheral nociceptor $\mathrm{C}$ and $\mathrm{A} \delta$ fibers to depolarize. This leads to the transmission of signals (signal transduction) via the dorsal horn to the cerebrum. During inflammation there is a hyperresponsive response whereby signal transmission to the dorsal horn does not require a stimulus. The hyperresponsive response can be controlled by NSAIDs [8].

In $\mathrm{OA}$ of the knee the diagnostic classification criteria include: knee pain and osteophytes on $\mathrm{X}$ ray and at least one of the following: crepitus (irregularity of opposing cartilage surfaces) on motion, morning stiffness lasting 30 minutes and age 
over 50 years [9]. These additional characteristics are required because pathogenic changes on X ray may occur without the patient demonstrating symptoms of pain.

The pathogenesis of $\mathrm{OA}$ is illustrated by degenerative changes to the articular cartilage of joints, new bone or osteophyte formation, loss of joint space between bone endings and sclerotic alterations to subchrondral bone. With the erosion of the articular cartilage, nociceptors become sensitized leading to chronic pain [10]. Pain can result from the stretching of the adjacent periosteum, growth of osteophytes, presence of microfractures, intraosseous pressure and synovitis [11]. The involvement of peri-articular tissues can also lead to joint pain, limitations in movement and disability $[12,13]$. Pain can arise from numerous sites; subchrondral bone, periosteum, joint capsule, synovial membrane, peri-articular muscles and ligaments.

Numerous cytokines have been implicated in the pathogenesis of OA. Interleukin -1 tumour necrosis factor $\mathrm{p}$ are thought to activate enzymes associated with the proteolytic digestion of cartilage [14]. Insulin growth factor 1 and tissue growth factor p may be involved in cartilage synthesis and repair processes [15]. OA develops when cartilage catabolism exceeds the process of cartilage synthesis. The cartilage catabolic process is maintained by several collagenolytic enzymes:

- Fibroblast collagenase 1 or matrix metalloproteinase -1

- Neutrophil collagenase2 or matrix metalloproteinase -2

- Collagenase 3 . 
Treatment options include non-pharmacological and pharmacological approaches. Non-pharmacological approaches include weight reduction, exercise, patient education and joint support. Pharmacological approaches include the use of regular analgesics such as paracetamol to control pain and symptoms, if joint effusion is present patients may need intra-articular injections of corticosteroids. For uncontrolled pain and symptom control the recent EULAR recommendations suggest that Non Steroidal Anti-Inflammatory Drugs (NSAIDs) can be used as apart of pain management or patients with OA of the knee. NSAIDs can also be used to manage peri-articular and extra articular joint disorders such as tendinopathies and could also be used to treat fibromyalgia [16].

A drawback of using NSAIDs is the severity of side effects affecting the gastrointestinal tract, renal complications and cardiotoxicity. Topical NSAIDs are postulated to produce fewer side effects especially cardiac related effects and better tolerability [17] as they are able to reach the target site either via cutaneous penetration or systemic delivery [18]. Cutaneous delivery refers to the delivery of a drug to the site of application where the drug is able to target the peripheral nerves and soft tissues local to the site of application [19]. Although many reports indicate the benefits and efficacy of topical NSAIDs as anti-inflammatory agents and analgesics, these benefits are contested [20, 21].

\section{Chemistry and pharmacokinetics properties}

Diclofenac is a non-steroidal anti-inflammatory drug (NSAID) and is a weak organic acids $(\mathrm{pKa}=4.00)$. Although this chemical attribute helps the drug to accumulate in 
inflammed tissues and improves their effectiveness as anti-inflammatory agents [22] a number of formulations have been developed to improve cutaneous absorption. .

The topical application of drugs is one of the oldest routes of drug delivery [19] as they can potentially achieve similar efficacy to oral formulations due to their ability to accumulate locally and achieve therapeutic concentrations without the risk of systemic side effects [23].

It is established that the tissue absorption properties of topical NSAIDs are favourable with good penetration of the synovial fluid as well as superficial joints. This is evidenced by good cutaneous absorption at the site of application particularly when the formulation of diclofenac includes biocompatible lecithin organogels. As this component aids the absorption of the drug through keratinocytes to access nonmyelinated C-fibers and melanocytes of the epidermal layer and also access the cutaneous nociceptive fibers of the dermis. In experimental studies. the efficacy of absorption was found to be dependent on the ability to be absorbed across the epidermal layers [24]. For good absorption, drugs need to ideally be of a low molecular weight ( $<500$ Daltons), possess hydrophobic characteristics to traverse the stratum corneum and be sufficiently hydrophiliac to traverse the aqueous epidermis [18].

In clinical studies, the formulation of diclofenac employed can alter the rate of absorption through the use of enhancing agents such as dimethyl sulfoxide (DMSO) particularly with repeated dosing [25]. Newer topical formulations such as N-(2hydroxyethyl)-pyrrolidine Epolamine (DHEP) is an epolamine salt which is formulated as a plaster bioadhesive or lecithin enriched gel containing 1.3\% DHEP 
which is more soluble in water and non-polar solvents compared to other formulations, its solubility properties allow the drug to interact with the cell membrane to promote its own absorption. penetration through the stratum corneum and concurrently carries hydrophobic and hydrophiliac drugs with improved cutaneous absorption $[26,27]$. This salt prep unlike other topical preparations such as diclofenac sodium, does not require DMSO to improve cutaneous penetration [28]. Good cutaneous absorption rates of 6-7\% of the dose administered can be achieved following repeated dosing with DHEP gel formulations with $1.32 \%$ or diclofenac diethylammonium $1.16 \%$. The integrity of the skin, effects of the vehicle and impact of dehydration can alter absorption [29, 30]. The DHEP plaster is absorbed locally $[31,32]$ with the ability to penetrate into joint space and surrounding soft tissues [31, 33]. It is suggested that the concentration difference of diclofenac DHEP in the synovial fluid was $30 \%$ of that found in the plasma at the same time point. Values were significantly different at $\mathrm{p}<0.05$ level with $1.02 \pm 0.38 \mu \mathrm{g} / \mathrm{L}$ versus $3.62 \pm 1.05 \mu \mathrm{g} / \mathrm{L}$ [31]. However, the difference in drug concentration between the plasma and synovial fluid can be as high as $60-80 \%$ which may relate to the lower levels of albumin in synovial fluid compared to the plasma [34].

Clinical studies also reported plasma concentration of DHEP of $15 \mathrm{ng} / \mathrm{mL}$ versus $1500 \mathrm{ng} / \mathrm{mL}$ in plaster formulations and oral formulations respectively [28]. As the plasma concentration is low it is unlikely that the main therapeutic effect of DHEP is due to plasma drug concentrations but related to the ability of the drug to maintain high local concentrations in the peri-articular tissues [33]. These plasma concentration values concur with those achieved by other topical gel formulations [32] and are reported to peak concentrations within 1-2 hours following application [29]. Plasma levels of DHEP patch were also compared to equivalent levels (50 mgs) of oral 
voltarol; $1.7 \pm 0.9 \mathrm{ng} / \mathrm{mL}$ and $1214 \pm 750 \mathrm{ng} / \mathrm{mL}$ in DHEP patch and oral voltarol, respectively. In experimental studies, the elimination half life $\left(\mathrm{t}_{1 / 2}\right)$ of diclofenac is about 3 times longer in synovial fluid compared to plasma [35] and reaches a peak at 3-4 hours after a single dose. The terminal half life of diclofenac in synovial fluid is round 5.2 \pm 1.1 hours. Steady state blood levels are reached after 4.5 days of drug administration [36]. The Cmax was10\% of that achieved by a similar dose was administered intramuscularly

Experimental evidence indicates that the depth of penetration of topical diclofenac measured using microdialysis probes assessed the interstitial concentrations in skeletal muscle compared to plasma. The mean $\mathrm{Cmax}$ was $18.75 \pm 4.97 \mu \mathrm{g} / \mathrm{L}$ in plasma compared to $219.68 \pm 66.36 \mu \mathrm{g} / \mathrm{L}$ in interstitial skeletal muscle which is a 12 fold difference and is a measure of the unbound drug fraction [37].

In experimental studies, diclofenac is metabolized by cytochome P450 (CYP2C) and undergoes hydroxylation during phase 1 and conjugation with glucuronic acid to form metabolites either as conjugates or sulfates during phase 2 . Up to $60-70 \%$ of metabolites are excreted in the urine [29] and up to $30 \%$ excreted in the bile. Although others indicate that $65 \%$ of the drug is excreted via the faecal route within 0-72 hours $[30,38]$. The evidence in support of metabolism and metabolic pathways is conflicting; this may be due to drug instability or the ability of spontaneous hydrolysis of glucuro-conjugated metabolites to reform the parent compound [29].

\section{Clinical efficacy}

There are a number of topical diclofenac preparations available for use in patients with OA of knee, hip or ankle or soft tissue injury. These include: sprays, gel, patch, 
bioadhesive plaster or lotion. Each product has been assessed and compared with oral forms of diclofenac or similar or alterative formulations $[36,39,40]$. Several studies have shown the therapeutic benefits of topical diclofenac and its role in pain management where sufficient concentrations of diclofenac is distributed to the target tissue and in so doing produces a therapeutic effect. There are currently a range of published studies, meta-analyses and systematic reviews, and working party recommendations that have explored the use of topical diclofenac as part of pain management for patients with OA of the knee [41-47], sports injury [19], soft tissue injury [36, 48-50], actinic ketatoses [51] and acute migraine attacks [52]. Key studies are identified in Table 1.for OA of the knee and Table 2 for sports injury studies and meta-analyses.

\section{Randomised clinical trials focused on OA of the knee}

Various formulations of topical diclofenac have been assessed in patients with OA of the knee. Bioadhesive plasters impregnated with DHEP have been shown to relieve pain during rest and improve movement and joint function in patients being treated for OA of the knee [28].

In RCTs involving patients with OA of the knee, $1.5 \%$ topical diclofenac induced a significant reduction in pain relief, morning stiffness and improvement in functional mobility and patient global assessment in patients in durations of 4 week [43], 6 week [42] and 12 week trials [46] compared to placebo. In these studies, minor skin dryness was a common complaint in $36-39 \%$ of patients. In 5-6\% of patients skin dryness lead to discontinuation of treatment $[42,46]$. More serious gastrointestinal complaints were limited and cardiovascular side effects were not evaluated. 
A drawback of published RCTs is the duration; longer trials e.g. studies greater than 12 weeks are needed that compare a larger spectrum of conditions related to acute and chronic pain in patients with OA of the knee.

\section{Meta-analyses of RCTS in OA.}

Several meta-analyses have shown that topical NSAIDs such as diclofenac can reduce the symptoms of pain associated with OA of the knee over a period of two weeks [41, 53]. In a recent 6 week study of 622 patients with $\mathrm{OA}$ of the knee topical $1.5 \%$ diclofenac solution provided equivalent pain relief as oral $50 \mathrm{mg}$ diclofenac capsules. Side effects were reported, topical diclofenac solution contains DMSO which is metabolized to dimethyl sulfone and dimethyl sulfide which causes a garlic like aroma / taste which can be offensive for patients. In addition, topical diclofenac caused dry skin in $27 \%$ of patients with $5 \%$ of patients experiencing a vesculobullous rash and significantly fewer gastrointestinal problems compared to oral diclofenac [41]. Patients receiving placebo also DMSO also experienced a rash at the site of application.

However contrasting findings are reported [45]. A recent recent meta-analysis of RCT oppose this view [45]. The pooled treatment effect of topical diclofenac compared to placebo in terms of pain relief was $0.41\left(95 \% \mathrm{CI}, 0.16-\right.$-0.66) $^{2}$ for week 1 and 0.4 (95\%, CI $0.15-0.65)$ for week 2. Topical diclofenac was superior to placebo only for the first two weeks of treatment. The data do not support the view that topical diclofenac is superior to oral drug forms in terms of pain relief or improvements in functional mobility and the authors call for a review of current guidelines for the management of OA of the knee, [44, 57]. However a pooled analysis of 2 RCTs 
involving 235 patients with OA comparing DHEP plaster containing $180 \mathrm{mg}$ of diclofenac to placebo [28, 40] and a meta-analysis of RCTs [41] suggest that topical diclofenac is advantageous as a drug of choice in patients with OA of the knee.

\section{Soft tissue injury RCTs and experimental studies}

The efficacy of topical diclofenac preparations have been assessed in patients presenting with soft tissue injuries, often for short durations. Recently it was reported that topical diclofenac prescribed QID for 14 days also led to significant reductions in pain on forced dorsiflexion in patients with lateral epicondylitis [54].

The effectiveness of diclofenac has been tested using different preparations. In an RCT, the efficacy of diclofenac pyrrolidine gel was compared to similar formulations with the addition of lecithin to treat mild-to-moderate post traumatic knee, ankle and muscle injuries [55]. Efficacy and safety data were collected in relation to measurements of pain on movement. In the first 3 days, the group receiving diclofenac pyrrolidine gel plus lecithin recorded significantly reduced pain compared to diclofenac pyrrolidine gel only. By day 10 of the study, the difference between groups was statistically significant. Findings indicate that the addition of lecithin to diclofenac pyrrolidine gel increases its pain relieving capability to produce a significant and more rapid therapeutic response compared to diclofenac pyrrolidine gel alone.

The benefits of the addition of lecithin to DHEP formulations has also been shown in 
patients with shoulder periarthritis and lateral epicondylitis. Findings showed a significant reduction in pain measured in $\mathrm{mm}$ by visual analogue scales (VAS);33.2 $\pm 26.1 \mathrm{~mm}$ in DHEP lecithin group compared to $-21.2 . \pm 18.8 . \mathrm{mm}$ in placebo [27].

Recently the use of bioadhesive DHEP plaster was assessed in patients with soft tissue injuries. The plaster significantly reduced pain intensity as measured by the Huskisson's visual analogue scale (VAS) by $59.9 \%$ compared to placebo $29.9 \%$. DHEP displayed similar efficacy to oral forms of diclofenac. It is also suggested that after the removal of DHEP plaster the duration of pain relief may extend up to 96 hours [56].

Similar studies in patients with sports and soft tissue injury have reported favourable results $[19,50]$. Both studies used topical diclofenac patches either containing either 140 mgs diclofenac sodium or $1.3 \%$ DHEP to provide pain relief compared to gelatin only placebo. In a two week study a visual analogue scale was used to measure pain intensity. Two hundred and thirteen patients with minor sports injuries were involved. Significant reductions in pain intensity were found compared to placebo on day 3 (p0.036) and day 14 (p0.048) [19]. Side effects reported included signs of pruritus in $5 \%$ of patients and $17 \%$ of placebo patients and gastrointestinal affects involving $6 \%$ or nausea involving $10 \%$ of patients in both drug and placebo groups.

In a similar study, 120 patients with acute impact injuries following injury involving a blunt instrument reported significant pain relief $(\mathrm{p}<0.0001)$ within 3 days of treatment using diclofenac patch compared to placebo [50]. Measurements such as tenderness, pressure and time for resolution of pain were taken over a period of 7 days [50]. 
Resolution of symptoms occurred in $73 \%$ of $(n=87)$ patients recovered within 7 days compared to $6.7 \%$ of the placebo group $(n=8)$. Tolerability of topical diclofenac was very good with $<10 \%$ of patients reporting side effects such as rash, pruritus.

\section{Meta-analyses involving soft tissue injury}

In a recent review of 19 RCTs, the efficacy of topical diclofenac as an antiinflammatory drug used in the management of pain was examined in 3000 patients with a history of OA and soft tissue injury [39]. Findings show that the application of topical diclofenac led to a reduction in pain intensity and inflammation in both chronic and acute conditions comparable to oral formulations of diclofenac and NSAIDs (ibuprofen, naproxen) as well as changes in mobility and functional capacity. Topical diclofenac was superior to placebo. In terms of safety and tolerability, topical diclofenac was associated with fewer side effects compared to oral forms and other NSAIDs, reports of mild skin irritation was noted [39].

\section{Pharmacodynamics}

Evidence from clinical and pharmacological studies imply that diclofenac exerts its actions by inhibiting cycloxygenase (COX) enzyme. There are two forms of the COX enzyme; COX-1 is associated with gastric epithelium; COX-2 is responsible for prostaglandin synthesis. Inhibition of COX-2 reduces the production of inflammatory mediators such as prostaglandins $[51,58]$, interleukin-6 and substance P. It is also suggested that diclofenac can alter G-protein mediated signal transduction pathways [19] and exerts an enhanced effect on hyperalgic muscle by directly interacting with nociceceptors [56]. 
Additional properties of diclofenac relate to the inhibition of murine angiogenesis and murine colonic adenocarcinoma [59] and collagenolytic and keratolytic effects [60].

\section{Safety and tolerability}

One of the drawback of using diclofenac as part of a pain management programme is the reports of adverse effects such as gastrointestinal bleeding, small bowel injury, upper and lower gastrointestinal harm and acute renal failure [61], anaemia [41]. The use of DHEP and diclofenac sodium patches are efficacious as a method of pain relief without the problems of systematic exposure $[36,50]$ and accompanying adverse side effects. In the studies available, the possible cardiac effects of topical diclofenac has not been reported or evaluated.

In more recent trials, topical $1 \%$ diclofenac gel was found to be efficacious in maintaining pain relief and improving physical function in patients with $\mathrm{OA}$ of the hand and knee $[62,63]$. Although some studies were of short duration they offer additional findings regarding the use of gel preparations [63]. In this study topical diclofenac was well tolerated with up to $48 \%$ of patients reported the drug as good or excellent in the management of their pain. Findings from a recent trial indicates that DHEP patch significantly reduced pain in patients with sports., localized strains and sprains with limited side effects reported [49].

A recent meta-analysis indicates that only $2.3 \%$ of patients administering DHEP developed mild cutaneous side effects such as urticaria and rash [28]. These findings contrast with a recent meta-analysis that reported that up to $15-20 \%$ of patients treated 
with topical NSAIDs experienced similar cutaneous side effects including pruritus [45]. This higher incidence concurs with published data particularly regarding the safety and tolerability data involving older people [64, 65].

\section{Conclusions}

Current studies indicate that topical diclofenac is a safe, well tolerated and efficacious option as a mode of treatment for resolution of pain in patients with OA knee or sports and soft tissue injury. These conclusions are mainly developed from studies that were of a duration greater than 2 weeks. One meta-analyses of shorter duration failed to support this view; this difference in opinion may be due to the formulation or excipient used.

\section{Expert opinion}

Topical diclofenac has been used to treat a number of soft tissue injuries and OA of the knee in patients who require both short-term and long-term pain relief but also need improvements in functional mobility. Numerous topical formulations of diclofenac are available, of those that incorporate lecithin, they appear to offer additional benefits in terms of cutaneous delivery, ability to concentrate in the synovial fluid compared to oral formulations and offer significant pain relief. Patients benefit from the application of topical diclofenac compared to oral administration in terms of ease of application and reduced systemic effects with only minor cutaneous adverse effects reported. Evidence from RCTs and meta-analyses support the view that topically applied diclofenac is comparable or better than oral formulations with regard to the ability to provide sustained pain relief and improve mobility. Medical 
and non-medical prescribers should be encouraged to use topical diclofenac formulated with lecithin as a treatment option.

Declaration of interest

The author has no conflict of interest to declare and no fee has been received for preparation of this manuscript

\section{References}

1.Bridgman SA, Clement D, Downing A. Population based epidemiology of ankle sprains attending accident and emergency units in the West Midlands of England, and a survey of UK practice for severe ankle sprains. Emerg. Med. J. 2003;20: 508-510.

2. Lawrence RC, Hochberg MC, Kelsey JL, MCDuffie FC, Medsger TA, Felts, WR, Estimates of the prevalence of selected arthritic and musculoskeletal diseases in the United States. J Rheumatol. 198 9;16 ; 427-241.

3. Felson DT, Lawrence RC, Dieppe RA, Hirsh R., Helmick CG, Jordan JM. Osteoarthritis: new insights Part 1: the disease and risk factors. Ann Intern Med. 2000; 43: 635-646.

4. Arden N, Newitt MC. Osteoarthritis epidemiology. Best Pract Res clin Rheumatol.,2006;20; 3-25.

5. Felson DT, Zhang, Y. An update on the epidemiology of knee and hip osteoarthritis with a view to prevention. Arthritis Rheum., 1998; 41; 1343-1355. 
6. Woolf AD, Pfleger B. Burden of major musculoskeletal conditions. Bull World Health Organ.. 2003: 81: 646-656.

7. Manek NJ, Lane NE. Osteoarthritis : Current concepts in diagnosis and management. American Academy of Family Physicians 2000;61: 1795-1804.

8. Kidd BL, Urban LA. Hui X, Hewitt PG, Poblete N, Maibach HI, Shainhouse JZ, Wester RC In Vivo bioavailability and metabolism of topical diclofenac lotion in human volunteers. Pharmaceutical Research 1998; 15: 1589-1595.

9. Altman R, Asch E, Bloch D, Bole D, Borenstein K., Brandt K. Development of criteria for the classification and reporting of osteoarthritis . Classification of osteoarthritis of the knee. Arthritis Rheum. 1991; 29:1039-1049.

10. Moskowitz EW, Holderbaum D. Clinical and laboratory findings in osteoarthritis . In : Koopman WJ, ed. Arthrititis and allied conditions.2001. $14^{\text {th }}$ Ed. Philadelphia: Lippincott Willaims and Wilkins, pp 2216-2243.

11. Barron MC, Rubin BR. Managing Osteoarthritic knee pain. JAOA. 2007; 6: ES21-ES27.

12. Felson DT, Chaisson CE, Hill CL. The association of bone marrow lesions with pain in knee osteoarthritis. Ann Intern.Med., 2001; 134: 541-519.

13. Hill CL, Gale DR, Chaisson CE. Knee effusions, popliteal cysts , and synovial thickening: association with knee pain in osteoarthritis. J. Rheumatol 2001; 28: 13301338.

14. Pelletier JP, DiBattista JA, Roughley P.,McCollum R, Martel-Pelletier J. Cytokines and inflammation in cartilage degradation. Rheum Dis Clin. North Am., 1993; 19: 545-568.

15. Malemud CJ. The role of growth factors in cartilage metabolism . Rheum. Dis Clin North Am. 1993; 19: 569-580. 
16. Galeazzi M., Marcolongo R. A placebo-controlled study of the efficacy and tolerability of a nonsteroidal anti-inflammatory drug. DHEP plaster, in inflammatory, peri and extra-articular rheumatological diseases. Drugs Exp.Clin. Res., 1993;19: 117127.

17. Moore RA, Tramer MR, Carroll D. Quantitive systematic review of topically applied non-steroidal anti-inflammatory drugs. BMJ. 1998; 16: 333-336.

18. Vaile JH, Davis P. Topical NSAIDs for musculoskeletal conditions. A review of the literature. Drugs 1998; 56: 783-799.

19. Galer BS, Rowbotham M, Perander J, Devers A, Friedman, E. Topical diclofenac patch relieves minor sports injury pain: results of a multicenter controlled clinical trial. J Pain Sympt.Management 2000; 19: 287-294.

20. Roth SH. A controlled clinical trial of $3 \%$ diclofenac $/ 2.5 \%$ sodium hyaluronate topical gel in the treatment of uncontrolled pain in chronic NSAID users with osteoarthritis. Int. J. Tiss React., 1995; 17:129-132.

21. Sandelin J, Harilainen A, Crone H. Local NSAID gel (eltenacP) in the treatment of osteoarthritis of the knee: a double blind study comparing eltenac with oral diclofenac and placebo gel. Scand J. Rheumatol. 1997; 26: 287-292.

22. Brooks PM, Day RO. Nonsteroidal anti-inflammatory drugs: differences and similarities. N. Eng. J. Med. 1991: 324: 1716-1725.

23. Cramer MP, Saks SR. Translating safety, efficacy and compliance into economic value for controlled release dosage forms. Pharmacoeconomics 1994; 70: 482-504.

24. Stanos SP Topical agents for the management of muscloskeletal pain. J. Pain Symptom Management 2007; 33: 342-355. 
25. Hewitt PG, Poblete N, Wester RC, Maibach HI, Shainhouse JZ. In Vitro cutaneous disposition of a topical diclofenac solution in human skin: Effect of a multi-dose regimen. Pharmaceutical Research 1998; 15: 988-992.

26. Conte A, Ronca G, Petrini M, Mautone G. Effect of lecithin on epicutaneous adsorption of diclofenac epolamine.Drugs Exp. Clin Res. 2002: 28: 249-255.

27. Spacca G, Cacchio A., Forgacs A, Monteforte P, Rovetta G. Analgesic efficacy of a lecithin-vehiculated diclofenac epolamine gel in shoulder periarthritis and lateral epicondylitis: a placebo-controlled multicenter, randomized, double-blind clinical trial. Drugs Exp Clin Res, 2005: 31: 147-154.

28. Brühlmann P, de Vathaire F., Dreiser R, Beat M. Short-term treatment with topical diclofenac epolamine plaster in patients with symptomatic knee osteoarthritis: pooled analysis of two randomized clinical studies. Current Medical Research and Opinion. 2006: 22: 2429-2438.

29. Davies NM, Anderson KE. Clinical pharmacokinetics of diclofenac. Clin. Pharmacokinetics 1997; 33: 184-213.

30. Giachetti C, Assandri A, Mautone G, Tajana E, Palumbo B, Palumbo R. Pharmacokinetics and metabolism of $\mathrm{N}$-(2-hydroxyethyl)-2,5-[14C]- pyrrolidine (HEP, Epolamine ) in male healthy volunteers. Eur. J. Drug Metab Pharmacokinet, 1996; 1: 261-268.

31. Gallacchi G, Marcolongo R. Pharmacokinetics of diclofenac hydroxyethylpyrrolidine (DHEP) plasters in patients with monolateral knee joint effusion. Drugs Exp. Clin, Res. 1993; 19: 95-103.

32. Assandri A, Canali S, Giachetti C. Local tolerability and pharmacokinetic profile of a new transdermal delivery DHEP plaster. Drugs Exp Clin Res., 1993; 19: 89-96. 
33.Affaitati G, Vecchiet F, Lerza R. Effects of topical diclofenac (DHEP plaster) on skin, subcutis and muscle pain thresholds in subjects without spontaneous pain. Drugs Exp Clin Res. 2001; 27: 69-76.

34. Brooks PM. NSAIDs in: Klippel JH, Dieppe PA (Editors). Rheumatology. 1994. London : Mosby . pp 8:10: 1-8.

35. Benson MD, Aldo-Benson m, Brandt KD. Synovial fluid concentrations of diclofenac in patients with rheumatoid arthritis and osteoarthritis. Semin.Arthritis Rhem., 1985; 1, 65-67

36. Rusca A, Mautone G, Sun S, Magelli M, Johnson F. Comparison of plasma pharmacokinetics of FLECTOR Patch (diclofenac epolamine topical patch) and oral volateren (diclofenac sodium enteric-coated tablets) in healthy volunteers. J.Pain, 2008; 9: Suppl 1; 45.

37. Muller M, Rastelli C, Ferri P. Transdermal penetration of diclofenac after multiple epicutaneous administration . J. Rheumatol, 1998; 9: 1833-1836.

38. Singh P, Robert MS. Skin permeability and local tissue concentrations of nonsteroidal anti-inflammatory drugs after topical application. J. Pharm.Exp.Ther., 1994; 268: 144-151.

39. Zacher J, Altman R., Bellamy N, Brulmanb P, DaSilva J, Huskisson E., Taylor RS. Topical diclofenac and its role in pain and inflammation : an evidence-based review. Current Medical Research and Opinion, 2008; 24: 925-950.

40. Grace D, Rogers J, Skeith K, Anderson K. Topical diclofenac versus placebo : a double-blind, randomized clinical trial in patients with osteoarthritis of the knee. $J$. Rheumatol, 1999; 26: 2659-2663. 
41. Towheed TE. Pennsaid (B therapy for osteoarthritis of the knee: A systematic review and meta-analysis of randomized controlled trials. J. Rheumatol 2006; 33: $567-573$.

42. Baer PA, Thomas LM, Shainhouse JZ. Treatment of osteoarthritis of the knee with a topical diclofenac solution: a randomized controlled, 6-week trial [ISRCTN53366886]. BMC Muscloskeletal Disorders 2005; 6:44-53.

43. Bookman ARM, Williams KSA, Shainhouse, JZ. Effect of a topical diclofenac solution for relieving symptoms of primary osteoarthritis of the knee:a randomized controlled trial. CMAJ;171:333-338.

44. EULAR Recommendations 2003: an evidence based approach to the management of knee osteoarthritis: Report of a task force of the standing committee for international clinical studies including therapeutic trials (ESCISIT). Jordan KM, Arden NK, Doherty M, Bannwarth B, Bijlsma JW, Dieppe P, Gunter K, Hauselman H, Herrero-BeauG, Kaklamanis P, Lohmander S, Leeb B, Lequesne M, Mazieres B, Martin-Mola E, Pavelka K, Pendleton A, Punzi L, Semi, U, Swoboda B, Verbruggen G., Zimmerman-Gorska I, Dougados, M. Ann Rheum Dis 2003; 62: 1145-1155.

45. Lin J, Zhang A, Jones A, Doherty M. Efficacy of topical non-steroidal antiinflammatory drugs in the treatment of osteoarthritis; meta analysis of randomized controlled trials. BMJ . 2004;329: 324-329.

46. Roth SF, Shainhouse JZ. Efficacy and safety of a topical diclofenac solution (Pennsaid) in the treatment of primary osteoarthritis of the knee. A randomized, double-blind, vehicle-controlled clinical trial. Arch. Int. Med. 2004; 164: 2017-2023. 47. Tugwell PS, Wells GA, Shainhouse JZ. Equivalence study of a topical diclofenac solution (Pennsaid®) compared with oral diclofenac in symptomatic treatment of 
osteoarthritis of the knee: A randomized controlled trial. J. Rheumatol, 2004; 31: $202-$ 212.

48.Belcaro B, Cesarone MR, Vinciguerra G, Ledda A, Dugall M, Di Renzo A, Stuard S, Ricci A, Cacchio M, Ippolito E, Hosoi MF, Fano P, Spignolli G. A plaster combining diclofenac and heparin: Microcirculatory evaluation in 2 models of high perfusion microangiopathy. Angiology 2005; 56: 707-713.

.49. Carr W, Beks P, Jones C, Rovati S, Magelli M, Sun S. Efficacy and tolerability of FLECTOR Patch (diclofenac epolamine topical patch) in the treatment of minor soft tissue injury pain. J.Pain 2008: 9: 45-52.

50. Predel HG, Koll R, Pabst H, Dieter R, Gallacchi G.,, Giannetti B, Bilitta M, Heidecker JL, Mueller EA. Diclofenac patch for topical treatment of acute impact injuiries: a randomized, double blind, placebo controlled, multicentre study. $\mathrm{Br}, \mathrm{J}$. Sports Med. 2004; 38: 318-323.

51. Ulrich C, Hackethal M, Ulrich M, Howork A., Forschner T., Sterry W, Stockfleth E. Treatment of multiple actinic keratoses with topical diclofenac 3\% gel in organ transplant recipients : a series of six cases. Br. J Dermatol 2007; 156: 40-42.

52. Vécsei L., Gallacchi G, Sági I, Semjéén J, Tajti J, Szok D., Müller M., Vadass P., Kerékgyórtó M. Diclofenac epolamine is effective in the treatment of acute, migraine attacks. A randomized. Crossover, double blind, placebo-controlled, clinical trial. Cephalgia. 2007: 27: 29-34.

53. Zhang LJ, Jones W, Doherty M. Efficacy of topical non-steroidal antiinflammatory drugs in the treatment of osteoarthritis : meta-analysis of randomized controlled trials. BMJ 2004; 329-324-326. 
54. Schapira D, Linn S, Scharf Y, 1991, A placebo-controlled evaluation of diclofenac diethyalamine salt in the treatment of lateral epicondylitis of the elbow. Curr.Ther.Res, 1991;49; 162-168.

55. Mahler P, Mahler F, Duruz H, Ramazzina M., Liguori V, Mautone G. Doubleblind, randomized, controlled study on the efficacy and safety of a novel diclofenac epolamine gel formulated with lecithin for the treatment of sprains, strains and contusions. Drugs Ex Clin Res.2003; 29: 45-52.

56. Solignac M. Assessment of a topical NSAIDs in the treatment of pain and inflammation. The example of Flector Plaster, a local bioadhesive plaster containing diclofenac epolamine. Presse Med. 2004: 33: 3S10-3S13.

57. Solignac M. Proof of the pharmacodynamic activity of Flector Plaster in healthy volunteers and patients suffering from osteo-arthritis of the knee. Presse Med. 2004; 33: 3S5-3S9.

58. White A. Osteoarthritis of the knee- an introduction. Acupuncture in Medicine. 2006; 24: S1-6.

59. Seed MP, Brown JR, Freemantle CN . The inhibition of colon 26 adenocarcinoma development and angiogenesis by topical diclofenac in $2.5 \%$ hyaluronan. Cancer Res, 1997; 57: 1625-1629.

60./Cortes R Correspondence Int, J. Dermatol 2002; 44: 371-373.

61. Moore, RA, Derry, S., Phillips CJ, McQuay HJ . Nonsteroidal anti-inflammatory drugs (NSAIDs), cycloxygenase-2-selective inhibitors (coxibs) and gastrointestinal harm: review of clinical trials and clinical practice. BMC Muscloskeletal Disorders 2006; 7: 79-91. 
62. Le Fevre M. Topical diclofenac gel delivers in osteoarthritis. Inpharma Weekly 2007; 1615: 9-10.

63. Kilminster SG, Mould GP. Comparison of diclofenac spray and gel on knee joints of patients with osteoarthritic pain. Clinical Drug Investigation, 1999; 18: 345-354

64. Evans JMM, McMahon A, McGilchrist M,White G, Murray F, McDevitt D. Topical non-steroidal anti-inflammatory drugs and admission to hospital for upper gastrointestinal bleeding and perforation: a record linkage case-control study. BMJ 1995'; 311: 22-26.

65. Figueras A, Capella D, Castel JM. Spontaneous reporting of adverse drug reactions to non-steroidal anti-inflammatory drugs: a report from the Spanish System of Pharmacovigliance, including an early analysis of topical, enteric coated formulations. Eur. J Clin. Pharmacol., 1994; 47: 297-303. 
Table 1. Characteristics of RCTs and meta-analyses involving OA of the knee

\begin{tabular}{|c|c|c|c|c|c|}
\hline PARAMETERS & BAER & $\overline{\mathrm{BOOKMAN}}$ & $\overline{\text { ROTH }}$ & TUGWELL & KILMINSTER \\
\hline Study & RCT & RCT & RCT & RCT & RCT \\
\hline Duration & 6 weeks & 4 weeks & 12weeks & 12 weeks & 1 week \\
\hline Sample & 216 & 248 & 326 & 622 & 43 \\
\hline Drug & $\begin{array}{l}1.5 \% \\
\text { dic. } \mathrm{Na}\end{array}$ & $1.5 \%$ dic $\mathrm{Na}$ & $\begin{array}{l}1.5 \% \\
\text { dic } \mathrm{Na}\end{array}$ & $\begin{array}{l}1.5 \% \text { dic } \\
\mathrm{Na} \text { vs oral } \\
\text { dic. }\end{array}$ & $\begin{array}{l}\text { Dic. spray } 35 \\
\text { mgs compared } \\
\text { to } 1 \% \text { dic gel }\end{array}$ \\
\hline $\begin{array}{l}\text { Pain relief } \\
\text { reduction }\end{array}$ & $\begin{array}{l}-5.2 \mathrm{vs} \\
3.3 . \mathrm{p}= \\
0.002\end{array}$ & $\begin{array}{l}-3.9 \text { vs }-2.5 \\
p=0.023\end{array}$ & $\begin{array}{l}-7.1 \text { vs }- \\
5.6 . \\
p=0.02\end{array}$ & $\begin{array}{l}4 \% \text { dic na } \\
\text { vs49\% oral } \\
\text { dic. }\end{array}$ & $\begin{array}{l}\text { Spray had a } \\
\text { faster onset of } \\
\text { action } \\
\text { compared to } \\
\text { gel }\end{array}$ \\
\hline $\begin{array}{l}\text { Physical } \\
\text { function } \\
\text { Improvement }\end{array}$ & $\begin{array}{l}-13.4 \mathrm{vs} \\
-6.9 \mathrm{p}= \\
0.01\end{array}$ & $\begin{array}{l}-11.6 \mathrm{vs}-8.4 \\
p=0.023\end{array}$ & $\begin{array}{l}-18.5 \text { vs } \\
-14.3 \\
p=0.04\end{array}$ & $\begin{array}{l}39 \% \text { dic na } \\
\text { vs } 46 \% \text { oral } \\
\text { dic. } 3\end{array}$ & $\mathrm{NA}$ \\
\hline $\begin{array}{l}\text { Stiffness } \\
\text { improvement }\end{array}$ & $\begin{array}{l}-1.8 \text { vs }- \\
0.9 \\
p=0.002\end{array}$ & $\begin{array}{l}-1.5 \text { vs }-0.7 \\
p=0.003\end{array}$ & $\begin{array}{l}-2.3 \text { vs }- \\
1.6 \\
p=0.02\end{array}$ & $\begin{array}{l}39 \% \text { dic na } \\
\text { vs45\% oral } \\
\text { dic. }\end{array}$ & NA \\
\hline $\begin{array}{l}\text { PGA } \\
\text { improvement }\end{array}$ & $\begin{array}{l}-1.3 \text { vs }- \\
0.7 \\
p=0.001\end{array}$ & $\begin{array}{l}-6.7 \text { vs } 7.8 \\
\text { p0.039 }\end{array}$ & $\begin{array}{l}-1.5 \mathrm{vs}- \\
1.2 \\
p=0.06\end{array}$ & $\begin{array}{l}43 \% \text { dic na } \\
\text { vs49\% oral } \\
\text { dic. }\end{array}$ & $\overline{\mathrm{NA}}$ \\
\hline Side effects & $\begin{array}{l}\text { Dry } \\
\text { skin in } \\
39 \% \text { of } \\
\text { cases }\end{array}$ & $\begin{array}{l}\text { Dry skin in } \\
36 \% \text { of } \\
\text { cases }\end{array}$ & $\begin{array}{l}\text { Dry skin } \\
\text { in } \\
36.6 \% \\
\text { of cases }\end{array}$ & $\begin{array}{l}\text { Dry skin in } \\
27 \% \text { of } \\
1.5 \% \text { Dic } \\
\text { Na cases } \\
\text { Pennesaid } \\
\text { was as } \\
\text { effective as } \\
\text { oral dic. }\end{array}$ & $\begin{array}{l}\text { No reported } \\
\text { adverse effects }\end{array}$ \\
\hline Reference no & & & & & \\
\hline
\end{tabular}

Dic Na refers to diclofenac sodium solution.

Oral dic. Refers to $50 \mathrm{mg}$ oral diclofenac capsules

Pain, physical function and stiffness were assessed using the WOMAC LK3.1 OA index criteria measured on a 5 -point likert scale where 0 indicates none, 1 indicates mild, 2 indicates moderate, 3 indicates severe and 4 indicates extreme. 
PGA refers to physical general assessment measured using a visual analogue scale from very good (0) to extreme (4).

Table 2. RCTs and meta-analyses of topical diclofenac use in soft tissue injuries and other uses

\begin{tabular}{|c|c|c|c|c|c|}
\hline$\overline{\mathrm{REF}}$ & $\begin{array}{l}\text { STUDY } \\
\text { POPULATION }\end{array}$ & $\begin{array}{l}\text { TREATMENT } \\
\text { REGIMEN }\end{array}$ & EFFICACY & $\begin{array}{l}\text { ADVERSE } \\
\text { EFFECTS }\end{array}$ & COMMENTS \\
\hline Galer & $\begin{array}{l}213 \text { patients } \\
\text { with history of } \\
\text { sprain, strain or } \\
\text { contusion of } \\
\text { less than } 72 \\
\text { hours aged } 18 \text { - } \\
75 \text { years }\end{array}$ & $\begin{array}{l}2 \text { week study } \\
\text { patients } \\
\text { randomized to } \\
\text { either DHEP } \\
\text { patch solution } \\
\text { or placebo }\end{array}$ & $\begin{array}{l}\text { Pain } \\
\text { reduction } \\
(\mathrm{p} 0.003) \text { at } \\
3 \text { days and } \\
(\mathrm{p}=0.036) \text { at } \\
14 \text { days } \\
\text { compared to } \\
\text { placebo }\end{array}$ & $\begin{array}{l}\text { Nausea and } \\
\text { GI effects } 6- \\
10 \% \text {, of } \\
\text { cases; } \\
\text { pruritus in } 5 \\
\% \text { of cases }\end{array}$ & $\begin{array}{l}\text { DHEP patch } \\
\text { was } \\
\text { efficacious in } \\
\text { reducing pain } \\
\text { following } \\
\text { sports related } \\
\text { injury } \\
\text { without major } \\
\text { side effects }\end{array}$ \\
\hline Predel & $\begin{array}{l}120 \text { patients } \\
\text { with a history } \\
\text { of trauma with } \\
\text { a blunt } \\
\text { instrument }\end{array}$ & $\begin{array}{l}1 \text { week study } \\
\text { randomized to } \\
140 \text { mg dic. } \\
\text { patch within } 3 \\
\text { hours of injury } \\
\text { or placebo } \\
\text { patch with } \\
\text { identical } \\
\text { excipient }\end{array}$ & $\begin{array}{l}73.3 \% \text { of } \\
\text { cases } \\
\text { reported a } \\
\text { reduction in } \\
\text { pain on } \\
\text { motion and } \\
\text { at rest } \\
\text { compared to } \\
\text { placebo } \\
(\mathrm{p}=0.0001)\end{array}$ & $\begin{array}{l}10 \% \text { of cases } \\
\text { reported } \\
\text { minor } \\
\text { pruritus or } \\
\text { rash in both } \\
\text { placebo and } \\
\text { drug group }\end{array}$ & $\begin{array}{l}\text { Tolerability } \\
\text { of dic. patch } \\
\text { was very } \\
\text { good }\end{array}$ \\
\hline Carr & $\begin{array}{l}418 \text { patients, } \\
\text { aged } 18-65 \\
\text { years with } \\
\text { history of knee, } \\
\text { ankle or foot } \\
\text { contusion, } \\
\text { sprain, or strain }\end{array}$ & $\begin{array}{l}\text { Patients } \\
\text { randomized to } \\
\text { DHEP patch } \\
\text { or placebo }\end{array}$ & $\begin{array}{l}57.8 \% \text { of } \\
\text { patients } \\
\text { treated with } \\
\text { DHEP } \\
\text { patch } \\
\text { showed a } \\
\text { pain } \\
\text { reduction } \\
\text { within } 3 \\
\text { days } \\
\text { compared to } \\
\text { placebo }\end{array}$ & $\begin{array}{l}7.9 \% \text { of drug } \\
\text { group and } \\
5.8 \% \text { of } \\
\text { placebo } \\
\text { group } \\
\text { reported } \\
\text { cutaneous } \\
\text { reactions at } \\
\text { the site of } \\
\text { application }\end{array}$ & $\begin{array}{l}\text { Dic. patch } \\
\text { was rated as } \\
\text { good to } \\
\text { excellent in } \\
\text { ability to } \\
\text { reduce pain }\end{array}$ \\
\hline Spacca & $\begin{array}{l}158 \text { patients } \\
\text { with history of } \\
\text { shoulder pain }\end{array}$ & $\begin{array}{l}10 \text { days cycle } \\
\text { of treatment } \\
\text { with DHEP } \\
\text { lecithin gel or }\end{array}$ & $\begin{array}{l}\text { Pain was } \\
\text { significantly } \\
\text { reduced by } \\
\text { DHEP gel }\end{array}$ & $\begin{array}{l}\text { No major side } \\
\text { effects } \\
\text { reported. }\end{array}$ & $\begin{array}{l}\text { DHEP } \\
\text { lecithin gel } \\
\text { was effective } \\
\text { in reducing }\end{array}$ \\
\hline
\end{tabular}




\begin{tabular}{|c|c|c|c|c|c|}
\hline & & placebo & $\begin{array}{l}\text { by day } 3 \\
(\mathrm{p}<0.001)\end{array}$ & & $\begin{array}{l}\text { pain for } \\
\text { patients with } \\
\text { shoulder pain }\end{array}$ \\
\hline Mahler & $\begin{array}{l}100 \text { patients } \\
\text { with mild to } \\
\text { moderate post } \\
\text { traumatic } \\
\text { injuries to } \\
\text { knee, ankle or } \\
\text { muscle injury }\end{array}$ & $\begin{array}{l}\text { Randomised to } \\
\text { either DHEP } \\
\text { gel or DHEP } \\
\text { lecithin. }\end{array}$ & $\begin{array}{l}\text { Pain on } \\
\text { movement } \\
\text { was better } \\
\text { with DHEP } \\
\text { lecithin } \\
\text { treatment at } \\
\text { both } 3 \text { and } \\
10 \text { days post } \\
\text { treatment } \\
(\mathrm{p}=0.036) .\end{array}$ & $\begin{array}{l}\text { Both groups } \\
\text { tolerated the } \\
\text { treatments } \\
\text { well with no } \\
\text { reported } \\
\text { adverse } \\
\text { effects }\end{array}$ & $\begin{array}{l}\text { DHEP } \\
\text { lecithin is } \\
\text { superior to } \\
\text { DHEP gel as } \\
\text { a method of } \\
\text { pain relief for } \\
\text { shoulder pain }\end{array}$ \\
\hline Towheed & $\begin{array}{l}\text { Meta analysis } \\
\text { of } 4 \text { RCTs } \\
\text { involving } 1412 \\
\text { patients mean } \\
\text { duration of } \\
\text { studies } 8.5 \\
\text { weeks }\end{array}$ & $\begin{array}{l}\text { Patients were } \\
\text { randomized to } \\
\text { dic.sodium } \\
\text { with DMSO } \\
\text { lotion } \\
\text { compared to } \\
\text { placebo or oral } \\
\text { diclofenac }\end{array}$ & $\begin{array}{l}\text { Dic. sodium } \\
\text { lotion } \\
\text { significantly } \\
\text { improved } \\
\text { pain, } \\
\text { physical } \\
\text { function } \\
\text { and PGA } \\
\text { and was } \\
\text { superior in } \\
\text { comparison } \\
\text { to placebo. }\end{array}$ & $\begin{array}{l}\text { All RCTs } \\
\text { reported } \\
\text { minor skin } \\
\text { irritation as a } \\
\text { side effect } \\
\text { from } \\
\text { application } \\
\text { of diclofenac. } \\
\text { sodium lotion }\end{array}$ & $\begin{array}{l}\text { Diclofenac } \\
\text { sodium is an } \\
\text { effective } \\
\text { topical } \\
\text { NSAID is a } \\
\text { safe } \\
\text { alternative for } \\
\text { treatment of } \\
\text { OA of knee. }\end{array}$ \\
\hline Brulmann & $\begin{array}{l}\text { Pooled } \\
\text { analyses of } 2 \\
14 \text { day RCTs } \\
\text { involving } 235 \\
\text { patients with } \\
\text { OA knee. }\end{array}$ & $\begin{array}{l}\text { Patients aged } \\
18-85 \text { years } \\
\text { with OA knee } \\
\text { were } \\
\text { randomized to } \\
\text { either DHEP } \\
\text { plaster or } \\
\text { placebo plaster }\end{array}$ & $\begin{array}{l}59.5 \% \text { of } \\
\text { patients } \\
\text { receiving } \\
\text { DHEP } \\
\text { plaster } \\
\text { reported a } \\
\text { reduction in } \\
\text { pain } \\
\text { intensity } \\
\text { compared to } \\
29.9 \% \text { of } \\
\text { placebo } \\
\text { group }\end{array}$ & $\begin{array}{l}\text { Good } \\
\text { tolerability to } \\
\text { the plaster } \\
\text { was reported } \\
\text { in both } \\
\text { groups. } 2.3 \% \\
\text { of patients } \\
\text { reported rash } \\
\text { or urticaria on } \\
\text { application of } \\
\text { the plaster }\end{array}$ & $\begin{array}{l}\text { DHEP plaster } \\
\text { is efficacious } \\
\text { and safe as a } \\
\text { mode of } \\
\text { short-term } \\
\text { treatment for } \\
\text { OA knee. }\end{array}$ \\
\hline
\end{tabular}


